\title{
Bekir Kuzudişli, Hadis Rivayetinde Bağlam: Sebebü îrâdi'l-hadîs, İstanbul: Klasik Yayınları, 2020 (ISBN: 978-975-2484-55-9)
}

\section{Bekir Kuzudisli, Context in Hadith Narration: Sababu Irad al- Hadith, Klasik Yayinlari 2020}

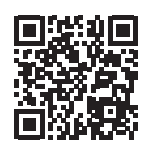

Ahmet Eşer ${ }^{1}$ (D)

'Sorumlu yazar/Corresponding author: Ahmet Eșer (Arş. Gör. Dr.), Balıkesir Üniversitesi Illahiyat Fakültesi, Hadis Anabilim Dalı, Balıkesir, Türkiye

E-posta: ahmet_esher@hotmail.com ORCID: 0000-0003-4948-8337

Makale Geliş: 25.08.2021

Revizyon Talebi/Revision Requested: 02.09.2021

Son Revizyon/Last Revision Received: 06.09.2021

Kabul/Accepted: 09.09.202

Atıf/Citation: Eşer, Ahmet. Bekir Kuzudiş̧i, Hadis Rivayetinde Bağlam: Sebebü îrâdi'l-hadîs, Istanbul: Klasik Yayınları. Islam Tetkikleri DergisiJournal of Islamic Review 11/2, (Eylül 2021): 1025-1028.

https://doi.org/10.26650/iuitd.2021.986986

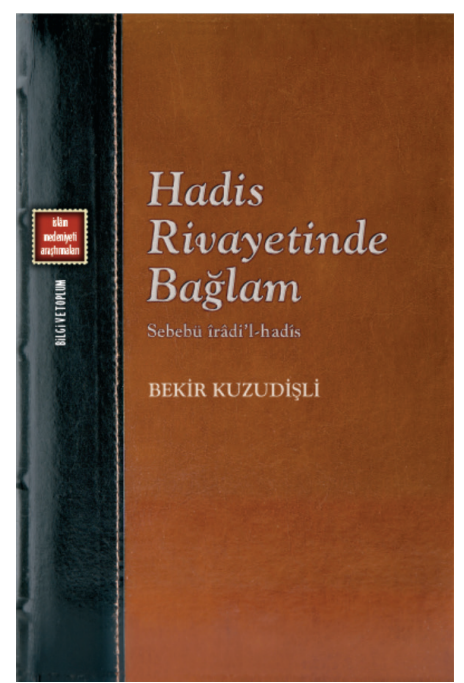

Anahtar Kelimeler: Hadis, İradu'l-Hadis, Rivayet Keywords: Hadith, Irad al-Hadith, Riwayat

Hadis tarihine dair çalışmalar, isnad kullanımında yaşanan dönüşüm dikkate alınmak suretiyle temel metinlerin derlendiğine işaret amacıyla tasnif öncesi ve sonrası şeklinde bir ayrıma tabi tutularak birçok çalışmaya konu olmuştur. Buna rağmen I/VII. asır ise günümüze ulaşan kaynakların azlığı sebebiyle dönemi yorumlamada yaşanan bazı sınırlılıklara sahip olduğu için nispeten yüzeysel anlatılmaktadır. Hâlbuki bir hadisin sahâbeden tâbiûn tabakasına geçişi yani rivayeti, genelde hadis tarihini ve özelde ise sünnetin nakledilme serüvenini kavramada son derece önemlidir. 
I/VII. asır hadis rivayetini ve ilgili dönemin yapısını anlamada önemli bir role sahip olduğu görülen sebebü îrâdi'l-hadise (hadisin rivayet sebebine) dair bilgiler, incelediğimiz kitabın hareket noktasıdır. Tanıtılan eserin başlığında, hem muhtevasını yansıtmak hem de hadis ilmi denilince rivayetlerin sebeplerine dair ilk zihne gelen "sebebü vürûdi'l-hadis" terkibinden ayırmak amacıyla "sebebü îrâdi'l-hadîs" kullanımı tercih edilmiştir.

Mezkûr kitap, giriş ve üç bölüm olarak tasnif edilmiştir. Girişte (s. 13-28), eserin metodu ve kaynakları ile çalışmanın odaklandığı "bağlam" ve "sebebü îrâdi'l-hadîs" kavramları vurgulanmaktadir.

Sebebü Îrâdi'l-Hadîs Işı̆̆̆ında Hadis Tarihini Yeniden Okumak başlıklı birinci bölümde (s. 29-100), bizzat hadis metinlerinden diğer bir ifadeyle bu metinlerin girişinde yer alan sebeb-i îrâdlar incelenmektedir. Hadislerin rivayet sebeplerinin I/VII. asır hadis rivayetini anlamadaki fonksiyonunu ortaya koymayı hedefleyen eser, ilk dönem hadis tarihini tedvin öncesi ve sonrası şeklinde ikili bir tasnife tabi tutularak irdelemektedir. Konunun daha iyi anlaşılması amacıyla ilk olarak, erken dönem hadis rivayetinde bir dönüm noktası teşkil eden tedvin faaliyeti ve sistemli hadis rivayeti incelenmektedir. Ardından tedvin öncesi rivayet şekilleri ise sebebü îrâdi'l-hadîs yani hadis rivayetinde bağlam başlığı altında ele alınmaktadır. İlk asırda hadisler, genel olarak olaylar meydana geldikçe rivayetlerin zihinde canlanması neticesinde ihtiyaca binaen veya yarı sistemli tarzda ilim halkalarında nakledilmektedir. Tedvin sonrasında ise söz konusu hadisler artık belli kural ve kaideler çerçevesinde hadis halkalarında sistemli olarak rivayet edilmeye başlanmıştır. Bu evre, rivayet anlayışının netleştirilmesi için ilk defa bir teklif mahiyetinde "sistemli hadis rivayeti", "ihtiyaca binaen hadis rivayeti" ve "yarı sistemli hadis rivayeti" kavramlarıyla ifade edilmiştir. Müksirûn ve mükillûn sahâbîlerden hareketle tahlil edilen yarı sistemli hadis rivayeti, tedvin öncesindeki rivayet ortamının yapısını ortaya koymak üzere seçilmiştir.

İhtiyaç Anında Rivayette Bulunan Sahâbîleri Hadis Nakline Sevkeden Etkenler (s. 101-192) başlığı taşıyan ikinci bölüm, I/VII. asırda hadis rivayetine vesile olan konulara ayrılmıştır. İdarecilik görevi, fitne olayları, zihne takılan çeşitli sorular, ibadetler ve günlük olaylar ile hatıralar bu bağlamda zikredilen hususlardandır. Sistemli hadis rivayeti dikkate alındığında bir sahâbînin idareci olması veya patlak veren fitne hadiseleri ilk bakışta ilim elde etme/nakletme açısından bir engel gibi görünse de aslında bunların hadislerin sahâbeden tâbiûna geçişinde rivayet edilmesine zemin hazırlayan etkenler olduğu söylenebilir. Bu bağlamda hilafet/idare makamına gelen bir sahâbînin, sistematik hadis rivayeti dikkate alındığında normal şartlarda meşguliyeti sebebiyle hadis naklinden uzak kalacağı düşünülürken ihtiyaca binaen hadis rivayeti söz konusu olduğunda bunun tam tersinin gerçekleştiği görülmektedir. Örneğin Hz. Osman'ın naklettiği hadislerin büyük kısmının hilafeti döneminde kendisine arz edilen meselelere binaen zikredilmesi veya fitne olaylarının yaşanan olumsuz hadiselere çözüm getirme hedefinden hareketle birçok hadisin rivayetine zemin oluşturduğu ifade edilebilir. Ancak burada ilgili sahâbenin öncelikli amacının, merfû bir hadis rivayetinden ziyade bir sorunu çözme, sorulan bir soruya fetva verme ve hac ya da oruç gibi bir ibadeti yerine getirme gayreti olduğu ifade edilmelidir. 
I/VII. asrın ikinci yarısına gelindiğinde geçen zaman diliminde sahâbîlere yöneltilen soruların farklılaştı̆̆ı, fikhî soruların yanı sıra Resûl-i Ekrem (s.a.v.) ile yaşanan şahsi ve duygusal hadiselerin ön plana çıktığı ve bunun benzer şekilde bunun maddi hatıralara da yansıdığı görülmektedir. Rasûlullah'ın bardağı, elbisesi, saç teli, na‘linleri gibi maddi hatıralara dair anekdotlar ve Hz. Peygamber'le yapılan bir savaşla alakalı hatıralardan hareketle dolaylı bazı meselelerin nakledilmesi bu kapsamda zikredilebilecek örneklerdendir.

Sebebü Îrâdi'l-Hadîs Bilgileri Işı̆̆ı̆nda I/VII. Asırda Hadis Meselelerine Yeniden Bakış (s. 193-287) unvanıyla ele alınan üçüncü bölümde, bazı hadis meselelerinin gözden geçirilmesi hedeflenmektedir. Bu kapsamda sahâbe algısında yaşanan değişim, hadis rivayetinin psikolojik boyutu ve hadis rivayetinde yerellik unsuru gibi konular incelenmektedir.

Büyük sahâbîler zamanında şahit isteme, Kurân'a veya Hz. Peygamber'in (a.s.) uygulamalarına arz ederek bunlara aykırı olanlara itiraz etme gibi uygulamaların, fitne olayları ve toplumda farklı fikirlerin yayılması gibi etkenlerle yaşanan güven kaybı neticesinde "Sen bunu Resûlullah’tan işittin mi?” şeklinde bir kaynak sorgulamasına dönüştüğü söylenebilir. Bu tür sorgulamaların yaygınlaşması, Enes b. Mâlik (r.a.) ve Ebû Saîd el-Hudrî (r.a.) başta olmak üzere sahâbîleri rahatsız edip öfkelendirmiştir. Bununla birlikte ilgili soruların, kimi zaman da meselenin herkes tarafindan bilinmeyecek bir hususta olması veya söz konusu sahâbînin meşhur olmaması gibi sebeplerden de kaynaklandığı bilinmelidir. Bu ihtimaller gündeme geldiğinde ise, bazen hadisi işiten başka bir sahâbînin desteği/şahitliği bazen de bir tâbiînin başka bir sahâbîye ilgili hadisi sorması yoluyla teyid edilerek rivayet etrafından ortaya çıkan sıkıntı bertaraf edilmiştir.

Hz. Peygamber döneminde yaşanan bazı olumsuz hadiselerin I/VII. asırdaki anlatımlarında muhataplar ve aileleri henüz hayatta oldukları için kalıcı tesirleri olabileceği endişesiyle onları incitmemek adına bazı sahâbîlerin her şeyin ayrıntısıyla anlatılmasına mesafeli yaklaştıkları anlaşılmaktadır. Birçok hususta sadece olay anlatılıp menfi konumdaki kişilerin yalnızca "bir adam" ifadesiyle kimliğinin gizlenmesi de aynı gayeye matuftur. Mesela Tahrim suresinde kalpleri kayan iki hanımın kim olduğu veya Vahşi’nin Hz. Hamza’yı nasıl şehit ettiği gibi nispeten özel ya da münafıkların isimlerinin tek tek sayılmaması tarzındaki görece genel konularda bu durumun yansıması açıkça görülmektedir. Benzer şekilde hanımların özel durumları ve aile hayatına dair mahrem konulara dair yapılan sorgulamalar da aile hayatına dair özel bazı noktaları ortaya çıkaracağı veya Hz. Peygamberin eşlerinin meselenin tarafı olması gibi nedenlerde psikolojik yönü ağır basan mevzulardır.

Hadis rivayetinde yerellik ifadesiyle ise çeşitli hadislerin ilk asırda büyük ölçüde belirli aileler, kabileler veya şehirlerde meşhur olması ve söz konusu rivayetlerin yoğun şekilde onlar tarafindan nakledilmesi kastedilmektedir. Örneğin Medinedeki Ensar ve Muhacirler ile Eş 'arîler'den veya Medine dışından gelen Abdülkays heyetinden kendileriyle alakalı rivayetler, nispeten daha uzun ve ayrıntılı nakledilmektedir. Bunların bizzat olayı yaşayan gruplar olması bu durumu makul kılarken fetihlerin ardından farklı bölge ve şehirlere dağılan sahâbîlerin ilminin/ 
rivayetlerinin, ikamet ettikleri bölgede toplanması ve daha çok orada meşhur olması tabii bir gelişme olarak kaydedilmelidir. Bu çerçevede Hicaz ve Irak bölgeleri öne çıkarken isnadların artık; "Haremeyn isnadları", "Yemen isnadları", "Şam isnadları" ve "Irak isnadları" şeklinde şehirlere nispet edildiği görülmektedir. Hadis rivayet tarihi dikkate alındığında tabii görülen bu durumun, hac ve umre maksadiyla Hicaz'a yapılan seyahatler veya rihlelerin sistematik hale gelmesiyle bölgeler arasındaki rivayet farkının azalarak hemen her coğrafyada mezkûr hadislerin yaygınlık kazandığı söylenebilir.

Bazı hadisler, bir sahâbîden birçok râvi kanalıyla nakledilirken kimi zaman da sadece bir kişi vasıtasıyla rivayet edildiği yani çoklu ve tekli isnadlarla kaydedilmiştir. Teferrüd diye isimlendirilen bu durum, isnadın aslu's-sened denilen sahâbî tarafiyla yani rivayetlerin sahâbî tabasından tâbiûna intikaliyle ilgilidir. Bu durum I/VII. asırdaki hadis rivayetinin genel yapısıyla alakalıdır. O sebeple Zehebî'nin belirttiği gibi tâbiûn ve etbâu’t-tâbiîn tabakasındaki tekli rivayetler sahih ve sahih-garîb diye isimlendirilmiştir. Tedvin sonrası sistemli hadis nakline geçildiği etbâu't-tâbiûnun öğrencilerinden itibaren ise artık garîb-ferd sayılan mezkûr rivayetlere şüphe ile yaklaşılmıştır. Dolayısıyla bir hadîs için garîb oluş doğrudan sıhhate engel değilse de teferrüd olgusuyla ilgili I/VII. asırdaki rivayetin yapısını ve tedvinden sonra ferd rivayetlere bakışı bilmek önem arz eder.

Nihayetinde hadis rivayetinde bağlam/sebeb-i îrâda dair tanıtılan bu çalışmanın en önemli katkıs1, bizzat hadis metinlerinden hareketle rivayetlerin sahâbeden tâbiûna intikal olgusunu zihinlerde netleştirmesidir. Bu kapsamda tedvin/sistemli hadis rivayeti öncesi hadis rivayet tarihinde nispeten kapalı olan I/VII. asrın ilk yarısı ile ikinci yarısında yaşanan dönüşüm, "yarı sistemli hadis rivayeti" ve "ihtiyaca binaen hadis rivayeti" şeklinde bir ayrıma tabi tutularak incelenmiştir. Müellif bunu yaparken tedvin sonrası sistemli hadis rivayetinde, bazı hadislerin belli bölgelerde şöhret bulması, idareci olma ve fitne olayları gibi etkenlerin hadis halkası kurmaya engel olduğu yaklaşımının her zaman geçerli olmadığını ifade eder. Ona göre ilk bakışta dezavantaj gibi görünen söz konusu etkenler, aslında tedvin öncesi rivayet tarihinin tabii akışına uygundur ve bizzat bunlar, birçok rivayetin nakledilmesine zemin hazırlamıştır. Böylece bir olgunun, dönemin şartları gereğince farklı yorumlanabileceği ve bir rivayetin/ sebeb-i îrâdın bazen üç dört açıdan delil olarak kullanılabileceği bu çalışmadan elde edilen diğer katkılardır. Eserin satır arasında sebeb-i îrâda dair örneklerin artacağı ve konunun farklı boyutlarıyla ele alınacağı müellifin bir başka bir çalışmasının müjdesinin verilmesi de ilgili literatürü zenginleştirecek bir haber olarak kaydedilmelidir (s. 134). 